\title{
ROW SPACING, CULTIVAR AND FUNGICIDE APPLICATION AFFECT THE INCIDENCE OF SOYBEAN STEM BLIGHT
}

\author{
ESPAÇAMENTO ENTRE LINHAS, CULTIVARES E APLICAÇÃO DE FUNGICIDA \\ AFETAM A INCIDENNCIA DA SECA DA HASTE EM SOJA
}

\author{
Nédio Rodrigo TORMEN ${ }^{1}$; Luiz Eduardo Bassay BLUM² \\ 1. Phytus Group, Planaltina, DF, Brazil; nedio.tormen@iphytus.com; 2. Biology Institute, Department of Plant \\ Pathology, University of Brasília, Brasília, DF, Brazil; luizblum@unb.br
}

\begin{abstract}
Brazil is a major soybean production country and cultivate yearly more than 36 million hectares. Several factors have been reported reducing soybean production and occurrence of diseases is one of the most important. Some diseases such as the pod and stem blight (Diaporthe phaseolorum var. sojae) can limit soybean yield by shortening plant cycle and reducing seed quality. Field experiments were conducted aiming to evaluate the effect of row spacing, soybean cultivar and fungicide application on the incidence of pod and stem blight on soybean. The trial was carried out twice, with planting date at 11/15/2012 and 12/15/2012, in Planaltina-DF, Brazil. Treatments were arranged in a split-split plot scheme obeying the randomized block design. The factors evaluated were row spacing (42, 60 and $75 \mathrm{~cm}$ ), soybean cultivars ("Syn1180RR" and "Syn1080RR") and spray or not the fungicide Boscalid (500 g a.i./ha) at R1 and R3 soybean growth stages. Disease incidence was assessed on stems at the harvest time and on seeds after harvest and yield was estimated. Results obtained show that broader row spacing increased disease incidence on stems and seed, cultivar "Syn1180RR" was more susceptible than "Syn1080RR" and fungicide application reduced disease incidence. Pod and stem blight significantly reduced soybean yield.
\end{abstract}

KEYWORDS: Diaporthe phaseolorum var. sojae. Control. Row spacing. Glycine max.

\section{INTRODUCTION}

Several factors limit soybean yield in Brazil and occurrence of diseases is certainly among the most important ones. Resistant cultivars to the major diseases are scarce and farmers have used fungicides extensively to control major foliar diseases (CRUZ et al. 2014). For the stem canker (Diaporthe phaseolorum f.sp meridionalis) infection, in the disease complex, the main control method is plant resistance (HILLEN et al 2006). Occurrence and damage potential of some diseases, commonly referred as "secondary diseases", like those caused by the Diaporthe / Phomopsis complex, have been underestimated.

Diaporthe phaseolorum var. sojae, causal organism of pod and stem blight (PSB), is reported to be less aggressive than $D$. caulivora and $D$. aspalathi, both causing stem canker. However, where the environmental conditions are favorable, PSB has limited soybean yield (PEDERSEN; GRAU, 2010). Reports available about this disease at Brazilian conditions are scarce and farmers lack information about control practices.

Previous studies carried out in North America showed that plants inoculated with the pathogen died seven to ten days before plants not inoculated, indicating the disease can accelerate the senescence process on plants (MCGEE, 1992). Additionally, fungicide application on soybean fields with high incidence of PSB has provided greater yields compared to fields with no fungicide (SOTO-ARIAS; MUNKVOLD, 2011).

Some authors have reported effects of management practices over PSB and showed that row spacing (SOTO-ARIAS; MUNKVOLD, 2011), genetic resistance of soybean cultivars (WRATHER et al., 2004) and fungicide application (WRATHER, et al., 2004; SOTO-ARIAS; MUNKVOLD, 2011) are practices with potential to reduce PSB incidence and increase soybean yield. However, these works were developed under temperate climate conditions, which can be different of Brazilian tropical conditions.

The higher occurrence of PSB in Brazil and uncertainty about its effects on soybean yield and seed quality have increased the concern of farmers, technicians and researchers with this disease. The objectives of this work were: (a) quantify the influence of row spacing, cultivars and fungicide on PSB incidence; (b) determine if PSB reduces soybean yield at Brazilian conditions and; (c) evaluate the effect of fungicide application on soybean yield. 


\section{MATERIAL AND METHODS}

The experiments were performed in Planaltina, Distrito Federal, during the 2012/2013 season, at location $15^{\circ} 39^{\prime} 57.70^{\prime \prime} \mathrm{S}, 47^{\circ} 20^{\prime} 4.66^{\prime \prime} \mathrm{W}$ and $875 \mathrm{~m}$ altitude. The soil is classified as an oxisoil and has been explored by agricultural activities since the 1980 's. Trials were installed in a field cultivated with soybean diseased by PSB during the three previous seasons.

The randomized complete block design with four replications was used and treatments were arranged in a split-split plot scheme. The factors were represented by row spacing $(42,60$ and 75 $\mathrm{cm}$ ), soybean cultivars ("Syn1180RR" and "Syn1080RR") and fungicide application. Row spacing represented the main factor, the cultivars were the subplots and fungicide application the sub subplots. Plots were 5 meters length and 3.5 meters width $\left(5.0 \times 3.5 \mathrm{~m}=17.5 \mathrm{~m}^{2}\right)$ and assessed area in each plot was 4 meters length and 3 meters width $\left(4.0 \times 3.0 \mathrm{~m}=12 \mathrm{~m}^{2}\right)$.

The field trial was set twice, with planting date in 11/15/2012 (Trial 1) and repeated in 12/15/2012 (Trial 2), which hereafter we call "Trial 1" and "Trial 2", respectively. Seed were treated with Cruiser ${ }^{\mathrm{TM}}$ (thiamethoxan - $35 \mathrm{~g}$ a.i $100 \mathrm{~kg}^{-1}$ of seed.) + Maxim XL ${ }^{\mathrm{TM}}$ (metalaxyl + fludioxonil - 1.0 $+2.5 \mathrm{~g}$ a.i. $100 \mathrm{~kg}^{-1}$ of seed) and inoculated with 6.0 x $10^{5}$ cells of Bradyrhizobium japonicum per seed. Plant density followed the recommendation for the cultivars and was the same (300.000 plants ha $\left.{ }^{-1}\right)$ for cultivars and row spacing tested.

The fungicide Cantus ${ }^{\mathrm{TM}}$ (Boscalid - $500 \mathrm{~g}$ a.i. ha ${ }^{-1}$ ) was sprayed over soybean plants at $\mathrm{R} 1$ and R3 growth stages, which are the timings most used for fungicide application on soybean in Brazil. Fungicide application was performed through constant pressure equipment $\left(\mathrm{CO}_{2}\right)$ and a boom spray with four XR11002 nozzles, calibrated to 200 $\mathrm{L} \mathrm{ha}^{-1}$.

In order to evaluate PSB incidence on soybean stems, one-meter length of central row of each plot was collected. These plants were sectioned into smaller pieces of approximately five centimeters length, which were individually analyzed to verify the presence/absence of PSB symptoms. This analysis was performed with a 200x digital lens (Digilab ${ }^{\circledR}$ 2.0). We determined the Incidence of PSB by the ratio between diseased and total stems and expressed the data in percentage.

Experiments were harvested in 03/20/2013 (Trial 1) and 04/15/2013 (Trial 2). Yield was estimated by harvesting the assessed area of each plot $\left(12 \mathrm{~m}^{2}\right)$. Grain mass and moisture were determined. Harvested weights obtained were standardized to $13 \%$ humidity.

Blotter test was used to determine disease incidence on seed (BRASIL, 2009). A $400 \mathrm{~g}$ sample of harvested seed was collected from each plot and 400 seed per sample were arbitrarily chosen and put into eight acrylic transparent "gerboxes" (25 seed gerbox $^{-1}$ ) over moistened filter paper. In order to reduce the seed germination process, filter paper was moistened with a 2,4-D solution (5 ppm). "Gerboxes" were kept under white light and incubated for seven days at $25{ }^{\circ} \mathrm{C}$. Incidence was determined through direct observation of seed using a stereomicroscope, based on the presence of fruiting structures of Phomopsis over seed. Results are presented in percentage of seed infested.

The statistical analysis of data from the two experiments was made separately. Shapiro-Wilk test was performed to check normality of data obtained. The data of disease incidence on stems and seed were transformed to " $\mathrm{x}=\sqrt{\mathrm{x}}$ ". Analysis of variance was performed, and averages were compared through the Tukey HSD $(\mathrm{p}<0.05)$. Data analysis was performed using the software Assistat v.7.7 beta.

\section{RESULTS}

\section{PSB incidence on stems}

Row spacing, soybean cultivar and fungicide application affected PSB incidence on stems in both trials. In the trial 1 , there was significant interaction for row spacing vs. cultivar and row spacing vs. cultivar vs. fungicide application. In the trial 2 , there was no interaction among the factors and just the main effect of row spacing, soybean cultivar and fungicide application affected PSB incidence. Results are presented in the interaction row spacing vs. fungicide, with soybean cultivars separated (Figure 1).

The incidence of PSB was greater in the broader row spacing $(75 \mathrm{~cm})$. The cultivar "Syn1180RR" was more susceptible and the fungicide application reduced disease incidence on stems in both trials (Figure 1). In the trial 1, the broader row spacing $(75 \mathrm{~cm})$ presented the higher PSB incidence $(38.3 \%)$ and was statistically close to $60 \mathrm{~cm}$ (32.3\%), but both differed from $42 \mathrm{~cm}$ $(24.8 \%)$. Average incidence in trial 2 was higher than in trial 1 , but results obtained were very similar; with higher incidence in row spacing $75 \mathrm{~cm}$ $(51.5 \%)$ and $60 \mathrm{~cm}(46.9 \%)$, compared to $42 \mathrm{~cm}$ $(30.6 \%)$. 

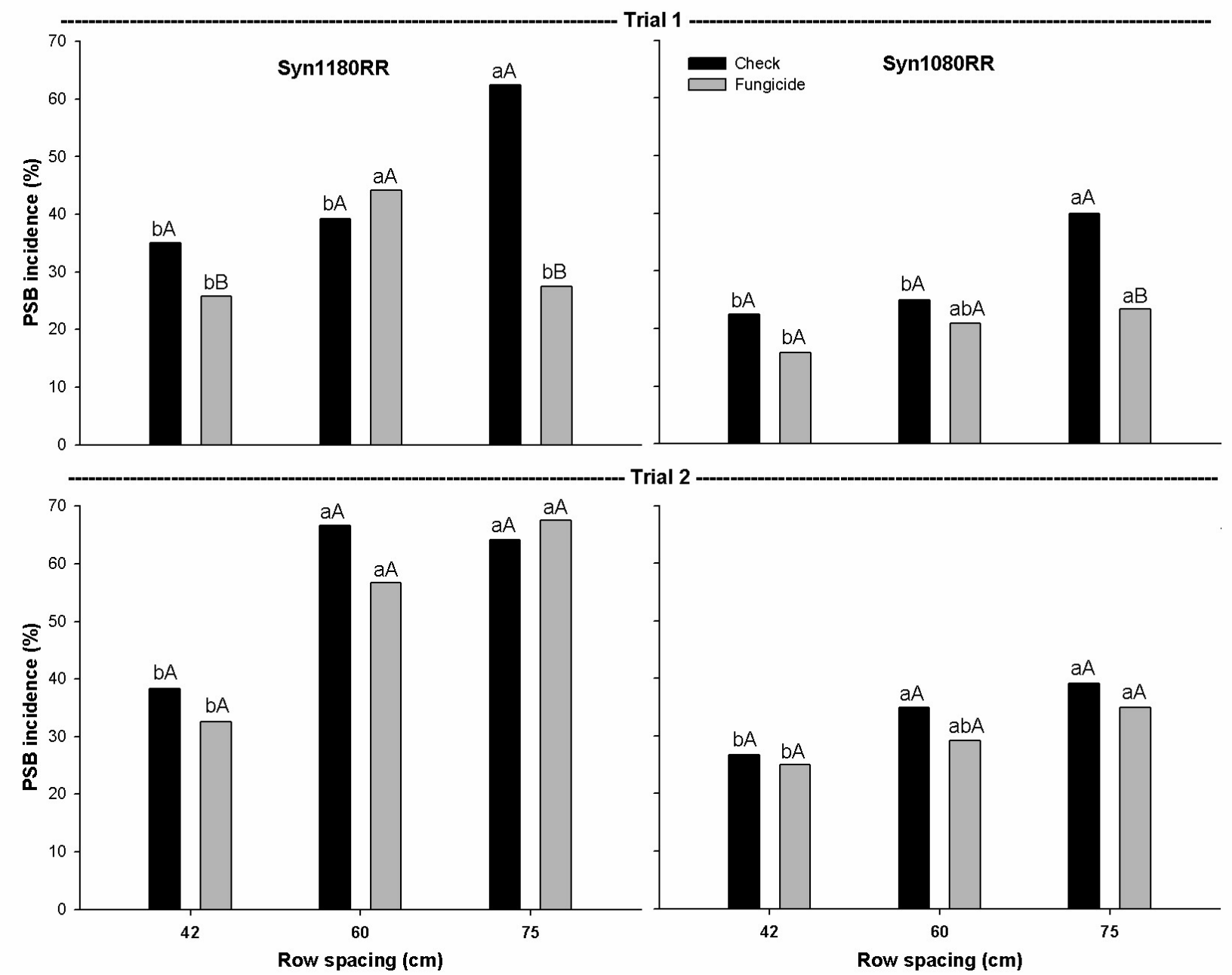

Figure 1. Incidence of pod and stem blight (PSB) on stems due to variations on row spacing, cultivar and fungicide application, in soybean cultivated in trial 1 and trial 2.

Different letters indicate significant differences among treatments by Tukey HSD $(p<0.05)$ (lower-case letters compare row spacing and capital letters compare fungicide, within each trial and cultivar). Coefficient of variation: Trial 1 - row spacing (11.17\%) cultivar (8.39\%) fungicide (7.55\%). Trial 2 - row spacing (6.95\%); cultivar (9.64\%); fungicide (8.12\%).

The cultivar "Syn1180RR" was more susceptible to PSB, showing an incidence in trial 1 of $39 \%$ comparing to $24.6 \%$ observed on "Syn1080RR". In trial 2, these values were $54.3 \%$ and $31.7 \%$, respectively. This difference represents $58.5 \%$ and $71.2 \%$ more disease in the cultivar "Syn1080RR", in trial 1 and trial 2, respectively.

Fungicide application significantly reduced stem infection by PSB both in trial 1 and trial 2. The fungicide efficacy was greater in trial 1 , in which reduced $40.3 \%$ and $46 \%$ of disease incidence in cultivar "Syn1180RR" and "Syn1080RR", respectively. In trial 2 the reduction was of $8 \%$ and $13 \%$. Analyzing the interaction between row spacing and fungicide application, it is very clear the stronger efficacy in $75 \mathrm{~cm}$ compared with $60 \mathrm{~cm}$ and $42 \mathrm{~cm}$.

\section{Seed infection by PSB}

Seed infection was impacted by row spacing and cultivar in trial 1 and was not affected by fungicide application in both trials. As there was no effect of fungicide, results are presented considering row spacing vs. cultivar interaction, averaging the factor fungicide (Figure 2).

Broader row spacing increased seed infection both in "Syn1180RR" and "Syn1080RR" cultivars. When row spacing changed from $42 \mathrm{~cm}$ to $75 \mathrm{~cm}$, seed infection increased $138 \%$ and $87 \%$ in the cultivar "Syn1180RR" and "Syn1080RR", respectively. Seed infection by PSB was greater in the cultivar "Syn1180RR", with an average of $19 \%$ of seed infected compared to $15 \%$ in the cultivar "Syn1080RR". 


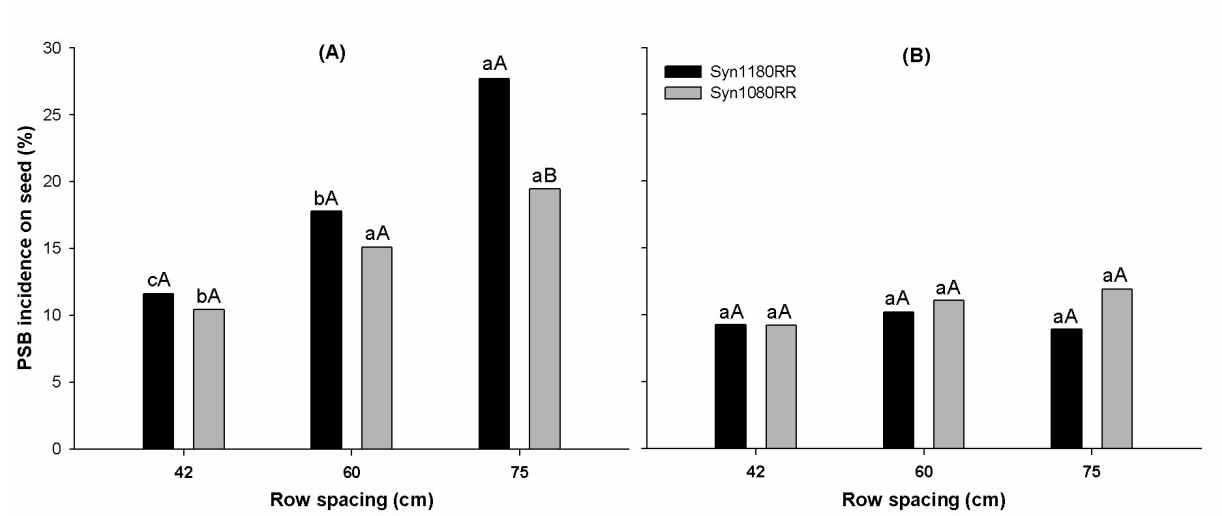

Figure 2. Incidence of Diaporthe phaseolorum var. sojae in seed due to variations in row spacing and cultivar, averaging factor fungicide, in soybean cultivated in trial 1 (A) and trial 2 (B).

Different lower-case letters for row spacing and capital letters for the cultivar indicate significant differences by Tukey HSD $(\mathrm{p}<0.05)$.

\section{Yield}

Row spacing, soybean cultivar and fungicide application affected soybean yield in both trials. There was significant interaction for row spacing vs. cultivar and cultivar vs. fungicide for yield in trial 2.

In trial 1, average yield was $3275 \mathrm{~kg} \mathrm{ha}^{-1}$ and the greater values were obtained with $42 \mathrm{~cm}$ row spacing, followed by $60 \mathrm{~cm}$ and $75 \mathrm{~cm}$, which were statistically similar. The cultivar "Syn1180RR" presented the greater yield with 3494 $\mathrm{kg} \mathrm{ha}{ }^{-1}$. Fungicide application increased yield by $14 \%$ in the cultivar "Syn1180RR" and $13.4 \%$ in the "Syn1080RR" (Figure 3).

Average yield was lower in trial 2 and achieved $2377 \mathrm{~kg} \mathrm{ha}{ }^{-1}$. The greater yield was obtained with $60 \mathrm{~cm}$ row spacing, followed by 75 $\mathrm{cm}$ and $42 \mathrm{~cm}$, which were statistically similar. Fungicide application did not impact yield in the cultivar "Syn1180RR", but increased yield in $8.6 \%$ in the cultivar "Syn1080RR".

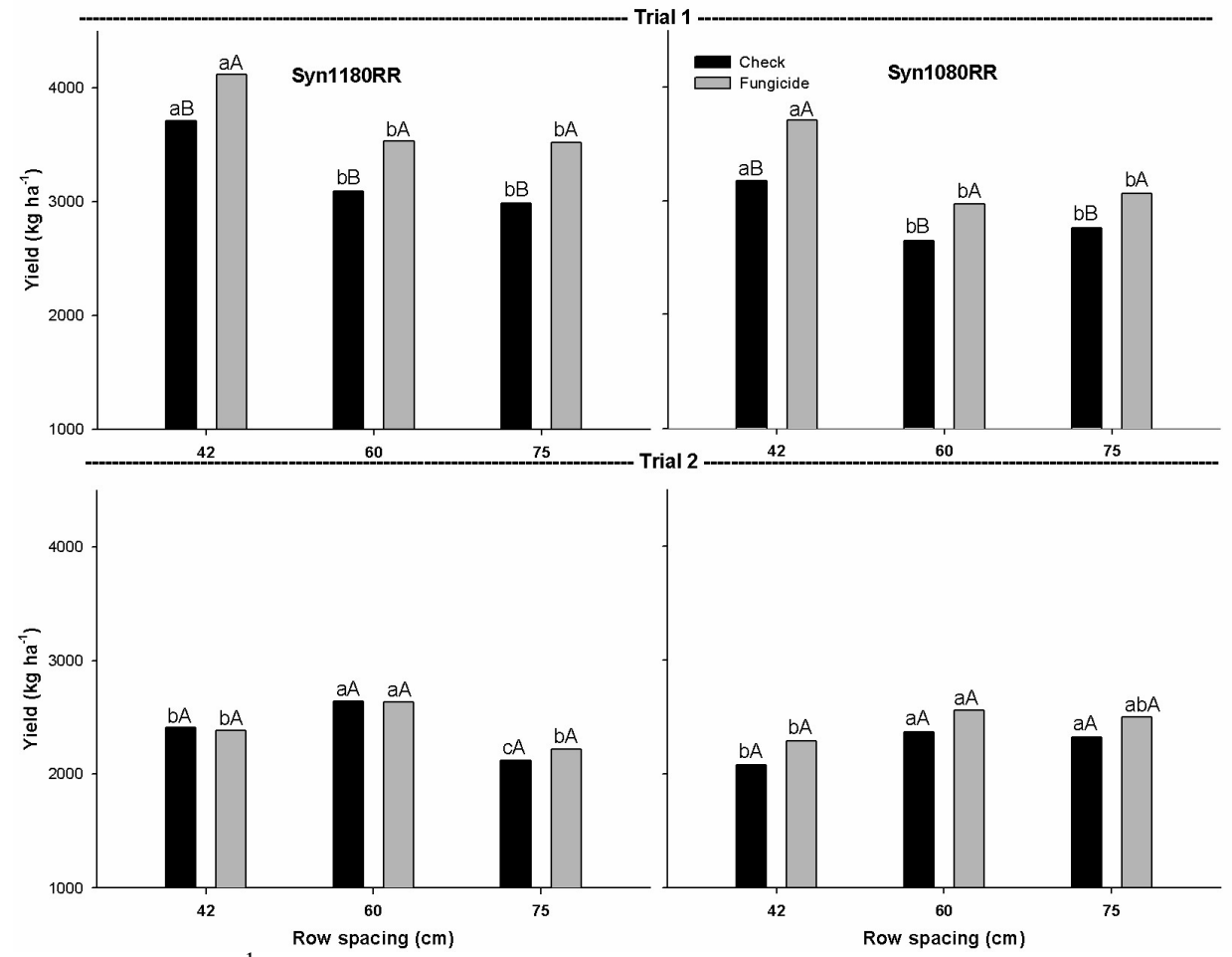

Figure 3. Soybean yield $\left(\mathrm{kg} \mathrm{ha}^{-1}\right)$ due to variations on row spacing, cultivar and fungicide application, in soybean cultivated in trial 1 and trial 2.

Different letters indicate significant differences among treatments by Tukey HSD $(p<0.05)$ (lower-case letters compare row spacing and capital letters compare fungicide, within each planting date). Coefficient of variation: trial 1 - row spacing $(3.62 \%)$, cultivar $(3.48 \%)$, fungicide $(4.36 \%)$. Trial 2 : row spacing $(3.56 \%)$, cultivar $(4.54 \%)$, fungicide $(4.69 \%)$. 


\section{DISCUSSION}

Considering data obtained in the two trials, PSB incidence on stems and seed was clearly higher in broader row spacing. The cultivars Syn1180RR and Syn1080RR were differentially susceptible to PSB and fungicide application consistently reduced the disease incidence, especially in trial 1. Management of these factors showed to have great potential to reduce PSB incidence and should be considered in disease management programs for soybean.

Based on previous results of Chin et al. (1993) and Pataki and Lim (1981) and considering the dispersion mode of the Diaporthe / Phomopsis complex reported by Yorinori (1996), we believe that higher row spacing could keep soil free of coverage for a longer period, favoring the dispersal of pathogen and increasing the disease incidence.

Conidia and ascospores of Diaporthe / Phomopsis formed over the soil are immersed in mucilaginous matrix and depend on rainfall for dispersion. Higher frequency and intensity of rain at early stages of soybean will possibly increase the pathogen dispersion (YORINORI, 1996). These reports agree with data obtained and explain the greater incidence of PSB in broader row spacing (PATAKI; LIM, 1981; MMBAGA; GRAY; ARNY, 1979).

Previous studies showed different results about the effect of row spacing and plant density over the Diaporthe / Phomopsis complex on soybean. Bowman et al. (1986) reported no effect of row spacing over the incidence of Phomopsis spp. in soybean. Chin et al. (1993) concluded that higher densities favored PSB incidence in soybean. However, the environmental conditions of the locations where these works were developed are different from Brazilian environment.

Fungicide applications have been reported to reduce severity of the Diaporthe / Phomopsis complex in soybean. Previous studies of Tekrony et al. (1985) and Wrather et al. (2004) observed reduction of seed infection by Phomopsis in response to application of Benomyl at R3, R5 and R6 stages of soybean. In addition, application of piraclostrobyn and tebuconazol also reduced the incidence of Phomopsis on soybean stems. (SOTOARIAS; MUNKVOLD, 2011).

In our experiment, however, fungicide application consistently affected just stem infection, showing no effect over seed infection. This result can be related to the time of fungicide application. In studies of Tekrony et al. (1985) and Wrather et al. (2004) the application occurred at R3, R5 and R6 growth stages, later than the R1 and R3 performed in our study. In Brazilian conditions, most of fungicide applications are concentrated at the beginning of reproductive stage, due to Phakopsora pachyrhizi infection.

Fungicide efficacy was higher in $75 \mathrm{~cm}$ row spacing compared with 60 and $42 \mathrm{~cm}$, probably because of greater penetration of fungicide on soybean canopy. Broader row spacing have allowed better control of some soybean diseases, as a result of unfavorable conditions for some diseases and enable greater deposition of fungicide in lower parts of plants (MADALOSSO et al. 2010; ROESE; MELO; GOULART, 2012).

Different levels of cultivar resistance to diseases are well documented for soybean. Wrather et al. (2004) found higher incidence of Phomopsis in the cultivar "Asgrow 3834" compared to the "SS936012". Among all the strategies reported to control $\mathrm{PSB}$, certainly the genetic resistance has been the most effective (ROY; ABNEY, 1988; JACKSON et al. 2009; PATHAN et al. 2009). In our experiment, however, association of genetic resistance to cultural practices and fungicide application showed to be more effective.

Data related to the effect of PSB over yield in Brazil were not found, but this disease has been reported to reduce soybean yield in another countries (KULIK; SINCLAIR, 1999; WRATHER et al. 2010; PEDERSEN; GRAU, 2010). In present study, the higher yield was obtained in plots that received fungicide in comparison to untreated ones. Absence of other diseases with significant severity, show a possible effect of the disease over yield.

\section{CONCLUSIONS}

Cultivar "Syn1180RR" is more susceptible than "Syn1080RR" to pod and stem blight (PSB).

'Boscalid' application reduced disease incidence and favored soybean yield increase (13$14 \%)$.

Greater row spacing favored a higher incidence of PSB on stems.

\section{ACKNOWLEDGMENTS}

The authors thank the 'Conselho Nacional de Desenvolvimento Científico e Tecnológico' (CNPq, Brazil) and the 'Coordenação de Aperfeiçoamento de Pessoal de Nível Superior' (CAPES, Brazil) for scholarships, and Phytus Institute, for providing the structure necessary to the development of this work. 
RESUMO: O Brasil é um dos principais países produtores de soja e cultiva anualmente mais de 36 milhões de hectares. Diversos fatores têm sido relatados reduzindo a produção de soja e a ocorrência de doenças está entre os mais importantes. Algumas doenças como a seca da haste e da vagem (Diaporthe phaseolorum var. sojae) podem reduzir a produtividade pelo encurtamento do ciclo e redução na qualidade da semente. Experimentos de campo foram conduzidos com o objetivo de avaliar o efeito do espaçamento entre linhas, cultivares e aplicação de fungicida sobre a incidência da seca da haste e da vagem na soja. $O$ experimento foi conduzido duas vezes, com semeadura da soja em 15/11/2012 e 15/12/2012, em Planaltina-DF, Brasil. Os tratamentos seguiram o esquema de parcelas sub-sub-divididas no delineamento de blocos ao acaso. Os fatores avaliados foram espaçamento entre linhas (42, 60 e $75 \mathrm{~cm}$ ), cultivares de soja ("Syn1180RR" e "Syn1080RR") e aplicação ou não do fungicida Boscalida nos estádios R1 e R3 da soja. A incidência da doença em hastes e sementes e a produtividade da soja foram mensurados. Os resultados obtidos mostram que espaçamentos mais amplos favorecem maior incidência da doença em hastes e sementes, a cultivar "Syn1180RR" é mais suscetível do que a "Syn1080RR" e a aplicação de fungicida reduz a incidência da doença. A seca da haste e da vagem reduz significativamente a produtividade da soja.

PALAVRAS-CHAVE: Diaporthe phaseolorum var. sojae. Controle. Espaçamento entre linhas. Glycine max.

\section{REFERENCES}

BOWMAN, J. E.; HARTMAN, G. L.; SINCLAIR, J. B.; HUMMEL, J. W.; WAX, L. M. Effects of weed control and row spacing in conventional tillage, reduced tillage, and nontillage on soybean seed quality. Plant Disease, St. Paul, V. 70, n. 7, p. 673-676, jul. 1986. https://doi.org/10.1094/PD-70-673

BRASIL. Ministério da Agricultura, Pecuária e Abastecimento. Manual de análises sanitárias de sementes. MAPA/ACS. Brasília, 2009. 200p.

CHIN, M. S.; KIM, S. H.; PARK, W. M. Effect of planting date, plant density, nitrogen level, harvest date and Benomyl treatment on Diaporthe phaseolorum var. sojae infection and germination of soybean seed. Journal of Agricultural Science, Madson, v. 35, n. 1, p. 99-108, 1993.

CRUZ, M. F. A.; RODRIGUES, F. A.; DINIZ, A. P. C.; ALVES MOREIRA, M.; BARROS, E. G. Soybean resistance to Phakopsora pachyrhizi as affected by Acibenzolar-S-Methyl, Jasmonic Acid and Silicon. Journal of Phytopathology, Malden, v. 162, n. 2, p. 133-136, fev. 2014. https://doi.org/10.1111/jph.12170

HILLEN, T.; JULIATTI, F. C.; POLIZEL, O. T.; HAMAWKI, O. T.; BRITO, C. H. Reação de genótipos de soja quanto a resistência ao cancro da haste. Bioscience Journal, Uberlândia, v.22, n.1, p.27-35,2006.

JACKSON, E. W, FENG, C.; FENN, P.; CHEN, P. Genetic mapping of resistance to Phomopsis seed decay in the soybean breeding line MO/PSD-0259 (PI562694) and plant introduction 80837. Journal of Heredity, Oxford, UK, v. 100, n. 6, p. 777-783, jul. 2009. https://doi.org/10.1093/jhered/esp042

KULIK, M. M.; SINCLAIR, J. B. Phomopsis seed decay and pod and stem blight. In: HARTMAN, G.L.; SINCLAIR, J.B.; RUPE, J.C. (eds.). Compendium of Soybean Diseases. American Phytopathological Society Press, St. Paul. 1999. p. 31-33.

MADALOSSO, M. G.; DOMINGUES, L. S.; LENZ, G.; DEBORTOLI, M. P.; BALARDINI, R. S. Cultivares, espaçamento entrelinhas e programas de aplicação de fungicidas no controle de Phakopsora pachyrhizi Sidow em soja. Ciência Rural, Santa Maria, v. 40, n. 11, p. 2256-2261, nov. 2010. https://doi.org/10.1590/S010384782010001100002

MCGEE, D. C. Soybean diseases: a reference source for seed technologists. Saint Paul: Society Press, 1992. $151 \mathrm{p}$. 
MMBAGA, M. T.; GRAY, C. R.; ARNY, D. C. Septoria brown spot of soybeans: Effect of row width and tillage practice on disease development. Phytopathology, St. Paul, v. 69, n. 5, p. 541, jun. 1979. (Abstract).

PATAKI, J. K.; LIM, S. M. Effects of row width and plant growth habit on Septoria brown spot development and soybean yield. Phytopathology, St. Paulo, v. 71, n. 10, p.1051-1056, 1981. https://doi.org/10.1094/Phyto71-1051

PATHAN, M. S.; CLARK, K. M; WRATHER, J. A.; SCIUMBATO, G. L.; SHANNON, J. G.; NGUYEN, H. T.; SLEPER, D. A. Registration of soybean germplasm SS93-6012 and SS93-6181 resistant to Phomopsis seed decay. Journal Plant Registrations, v. 3, n. 1 p. 91-93, jan. 2009. https://doi.org/10.3198/jpr2008.01.0002crg

PEDERSEN, P.; GRAU, C. R. Effect of Agronomic Practices and Soybean Growth Stage on the Colonization of Basal Stems and Taproots by Diaporthe phaseolorum var. sojae. Crop Science, Madson, v. 50, n. 2, p. 718722, mar/abr. 2010. https://doi.org/10.2135/cropsci2009.06.0289

ROESE, A. D.; MELO, C. L. P.; GOULART, A. C. P. Espaçamento entre linhas e severidade da ferrugemasiática da soja. Summa Phytopathologica, Botucatu, v. 38, n. 4, p. 300-305, 2012.

https://doi.org/10.1590/S0100-54052012000400005

ROY, K. W.; ABNEY, T. S. Colonization of pods and infection of seed by Phomopsis longicolla in susceptible and resistant soybean lines inoculated in the greenhouse. Canadian Journal of Plant Pathology, v. 10, n. 4, p. 317-320, dec. 1988. https://doi.org/10.1080/07060668809501705

SOTO-ARIAS, J. P.; MUNKVOLD, G. P. Impacts of foliar fungicides on infection of soybean by Phomopsis spp. in iowa. Crop Protection, v. 30, n. 5, p. 577-580, mai. 2011. https://doi.org/10.1016/j.cropro.2010.11.018 TEKRONY, D. M.; EGLI, D. B.; STUCKEY, R. E.; LOEFFLER, T. Effect of Benomyl applications on soybean seedborne fungi, seed germination, and yield. Plant Disease, St. Paul, v. 69, p. 763-765, sep. 1985. https://doi.org/10.1094/PD-69-763

WRATHER, J. A.; SHANNON, J. G.; STEVENS, W. E.; SLEPER, D. A.; ARELLI, A. P. Soybean cultivar and foliar fungicide effects on Phomopsis sp. seed infection. Plant Disease, St. Paul, v. 88, n. 7, p. 721-723, jul. 2004. https://doi.org/10.1094/PDIS.2004.88.7.721

WRATHER, A.; SHANNON, G.; BALARDIN, R.; CARREGAL, L.; ESCOBAR, R.; GUPTA, G. K.; TENUTA, A. Effect of diseases on soybean yield in the top eight producing countries in 2006. Plant Health Progress, v. 125, p. 1-3, jan. 2010. https://doi.org/10.1094/PHP-2010-0102-01-RS

YORINORI, J. T. Cancro da haste da Soja: epidemiologia e controle. Londrina: Embrapa, CNPSo, 1996. $75 \mathrm{p}$. 